\title{
Transformation of the Flue Gas Side for fully Loaded SCR Denitration in the Coal-fired Power Plant
}

\author{
Gaojun Liü ${ }^{1, a}$, Long Jiang ${ }^{1, b}$, Lei Du ${ }^{1, c}$, \\ Yue Guo ${ }^{1, d}$ and Qing $\mathrm{Li}^{1, \mathrm{e}}$ \\ ${ }^{1}$ North China Electric Power Research Institute Co. Ltd., Beijing, 100045, China. \\ aliu.gao.jun@163.com, ${ }^{b} 18810438746 @ 163 . c o m,{ }^{c}$ dulei426311@163.com, \\ dhosa0603@163.com, ${ }^{\mathrm{e}}$ ncepri@139.com
}

Keywords: Boiler environmental protection, denitration, catalyzer, full load.

\begin{abstract}
The flue gas temperature of inlet and outlet of the selective catalytic reduction (SCR) device in the normal operation of coal-fired power plant in China is between $320^{\circ} \mathrm{C}$ and $420^{\circ} \mathrm{C}$ to meet the basic performance of catalyst temperature requirements. However, the low temperature of the flue gas flowing through the SCR device at low load is much lower, and the catalytic capacity of the catalyst is greatly reduced, which can not reduce the concentration of $\mathrm{NO}_{\mathrm{X}}$ emission. Therefore, it is of great significance to study the full load denitration technology. The transformation of the flue gas side for fully loaded SCR denitration in coal-fired power plant can change the flue gas path, improve the operating temperature of the SCR device, and ensure the efficiency of the catalyst.
\end{abstract}

\section{Introduction}

Coal occupies an important position in primary energy structure in China, and this energy structure will exist for a long time in the future. However, the nitrogen, sulfur and ash in coal can be discharged into the atmosphere in the form of nitrogen oxides, sulfur dioxide and particulate matter in the combustion process, which can cause environmental pollution [1].

In this regard, the document "Energy saving emission reduction upgrade and transformation action plan for coal-fired power plants (2014-2020)” points out the direction of ultra-low emission. High efficiency desulfurization, denitrification and dust removal facilities must be installed in coal-fired generating units. The plants can not meet the emission standards to accelerate the implementation of environmental protection equipment upgrades, to ensure that the minimum technical output to meet the full load, full time stable discharge requirements. The emission concentration of dust, sulfur dioxide and nitrogen oxides are not higher than $10,35,50 \mathrm{mg} / \mathrm{m}^{3}$ respectively, under the condition of $6 \%$ oxygen content.

At present, the NOx emissions from coal-fired power plants must be less than the emission limits of $50 \mathrm{mg} / \mathrm{Nm}^{3}$. Reducing NOx emissions can be achieved from two ways of reducing nitrogen in combustion and reducing nitrogen after combustion. Nitrogen reduction in combustion mainly refers to low nitrogen combustion technology, including low nitrogen burners, fuel staged combustion technology, air staged combustion technology and so on. Reducing nitrogen after combustion mainly refers to the post combustion flue gas denitration technology, including the selective catalytic reduction (SCR), selective non catalytic reduction (SNCR) and hybrid SNCR/SCR flue gas denitration technology. The SCR technology is the current mainstream technology for the denitration in most power plants.

The flue gas temperature of inlet and outlet of the selective catalytic reduction (SCR) device in the normal operation of coal-fired power plant in China is between $320^{\circ} \mathrm{C}$ and $420^{\circ} \mathrm{C}$. However, under the condition of low load, the reaction temperature is lower than that at high load, and the catalyst performance is not very good [2,3]. The transformation of the flue gas side for fully loaded SCR 
denitration in coal-fired power plant can change the flue gas path, improve the operating temperature of the SCR device, and ensure the efficiency of the catalyst [4,5].

\section{Fully Loaded SCR Denitration}

At present, SCR and SNCR are mainly used for denitrification in domestic coal-fired power plants. In contrast, SCR is widely used in power plants to control the emission of NOx. SCR flue gas denitrification process is mainly that nitrogen oxides are reduced to nitrogen and water by ammonia catalyst. Nitrogen oxides usually participate in the following chemical reactions [1]. Flue gas SCR denitration reaction diagram shown in figure 1.

$$
\begin{gathered}
4 \mathrm{NO}+4 \mathrm{NH}_{3}+\mathrm{O}_{2} \rightarrow 4 \mathrm{~N}_{2}+6 \mathrm{H}_{2} \mathrm{O} \\
6 \mathrm{NO}+4 \mathrm{NH}_{3} \rightarrow 5 \mathrm{~N}_{2}+6 \mathrm{H}_{2} \mathrm{O} \\
2 \mathrm{NO}_{2}+4 \mathrm{NH}_{3}+\mathrm{O}_{2} \rightarrow 3 \mathrm{~N}_{2}+6 \mathrm{H}_{2} \mathrm{O} \\
6 \mathrm{NO}_{2}+8 \mathrm{NH}_{3} \rightarrow 7 \mathrm{~N}_{2}+12 \mathrm{H}_{2} \mathrm{O} \\
\mathrm{NO}+\mathrm{NO}_{2}+2 \mathrm{NH}_{3} \rightarrow 2 \mathrm{~N}_{2}+3 \mathrm{H}_{2}
\end{gathered}
$$

The inlet flue gas temperature of the denitration unit changes with the boiler load. When the boiler load drops to $50 \% \sim 60 \%$ of the unit load, the inlet temperature of the reactor is lower, and the activity of the catalyst is lower. Ammonia reacts with $\mathrm{SO}_{3}$ in the flue gas to produce ammonia hydrogen sulfate, which is deposited on the catalyst and the air preheater corrugated plate. The reaction products can result in the decrease of catalyst activity and the adverse effects of blocking the air preheater.

The domestic and foreign SCR system mostly adopts the high temperature catalyst, so at lower load the entrance gas temperature of the existing SCR does not meet the conditions of the denitration device. The transformation of the flue gas side for fully loaded SCR denitration in coal-fired power plant can improve the temperature of the flue gas from the reactor entrance. This kind of reform mainly focuses on the boiler side reconstruction.

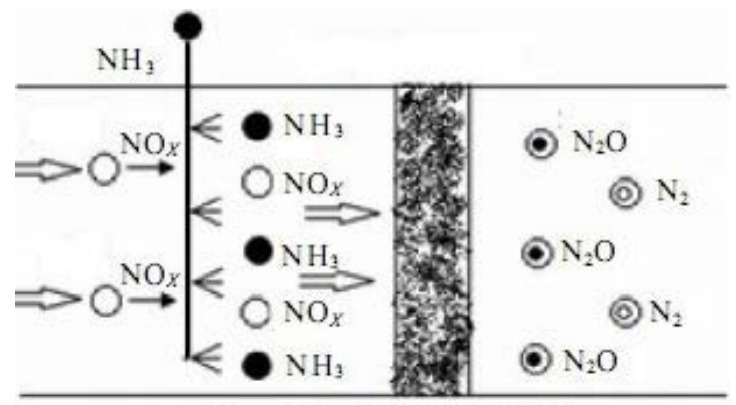

Fig. 1 Schematic diagram of flue gas SCR denitration reaction

Full load denitration technology is mainly involved in the transformation of the boiler side and low-temperature catalyst. The reformation of the boiler side is divided into the flue gas side transformation and the feed side transformation. This article mainly discusses the flue gas side transformation which includes the coal-economizer flue gas bypass, economizer separator, economizer classification and so on. 


\section{Transformation of the Flue Gas Side}

\subsection{Economizer Bypass}

If the existing power plants install the economizer flue gas bypass, the flue gas at low load will not continue to heat the water supply and directly flow into the SCR device. The outlet flue gases from the economizer bypass and economizer outlet can mix together to improve the flue gas temperature of the SCR device inlet at low load, which can ensure the efficiency of the denitrification device [6]. The SCR system with the economizer bypass shown in figure 2 .

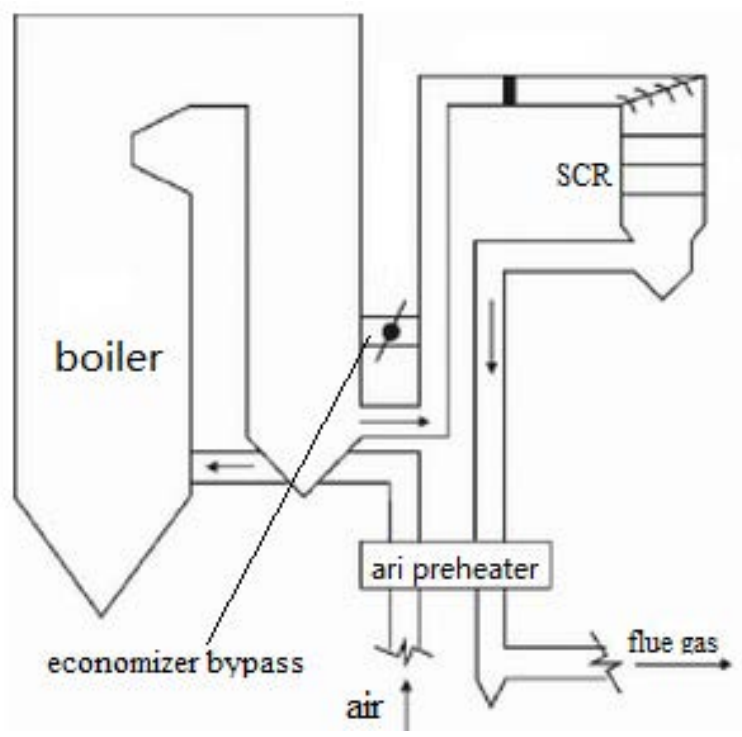

Fig. 2 SCR system with the economizer bypass

In the current situation, the recent grid load rate for many power plants is low. The long-term low load can cause that flue gas temperature of the SCR inlet decreases wish the negative impact of the reducing denitrification efficiency, the blockage of the ammonia injection grid and the blockage of air preheater. Of course, the transformation of economizer flue gas bypass can improve the flue gas temperature, which directly improves the denitrification efficiency and reduces the low-temperature corrosion and ash blocking effect. In terms of several common flue gas side reforming methods, the reforming cost of the economizer bypass flue gas is low [7]. The construction difficulty is small and it is easy to realize.

\subsection{Economizer Separator}

Economizer separation is defined as that the economizer flue gas channel are divided into a number of parallel independent of the flue gas flow channel with the flue gas baffle for the inlet and outlet of every channel. At low load, workers just adjust the angle of flue gas baffle, which indirectly control the heat transfer between the flue gas and boiler water. Because the transformation improves the flue gas temperature to ensure that the catalyst performance of denitrification device in normal working condition.

Such reconstruction does not require a new bypass flue, and there is less demand for the reserved space. As the need to the flue gas baffle of the economizer's inlet and outlet, the system resistance increases and the output of induced draft fan should be checked whether to meet the operational requirements. At the same time, the new electronic control gate also increases the complexity of the DCS control system, which maybe cause the new potential failure.

\subsection{Economizer Classification}

The economizer classification is to move the economizer of the economizer to the inside of the denitrification unit. By reducing the heat absorption of the economizer between the flue gas and boiler water, the flue gas temperature of the inlet of the denitrator is improved, and the environment of the catalyst is maintained under the normal working condition. 
Such retrofits involve the grading of the economizer. Existing economizers need to be segmented, and the boiler tail flue and SCR units need to be retrofitted. Although it is theoretically feasible, the engineering transformation is less due to the high cost.

\section{Summary}

The temperature of the flue gas in the denitrification unit is lower than the optimum working temperature of the catalyst used for the SCR reaction when the coal-fired power plant just starts or runs in the low-load operation. So the performance of the catalyst can not be normalized and the SCR denitrification efficiency is low and difficult to meet the environmental requirements, which is likely to cause excessive nitrogen oxide emissions.

The transformation of the flue gas side for fully loaded SCR denitration in the coal-fired power plant mainly reduces the heat transfer between the flue gas and the water supply, which can improve the flue gas temperature in the denitrification device. The transformation can meet the normal working temperature of the catalyst, ensure the reaction efficiency of the denitrification device, and achieve the environmental emission indicators. The transformation of the flue gas side includes the coal-economizer flue gas bypass, economizer separator, economizer classification and so on. Among them, the flue gas bypass is the least difficult, the least cost, and the most easy to achieve.

With the continuous improvement of China's economic level and the continuous improvement of flue gas emission standards, the environmental indicators of SCR denitrification plant in coal-fired power plants will gradually become strict. In the future the low NOx emissions will be the focus of environmental transformation requirements.

\section{References}

[1] G. Centi, S. Perathoner, Introduction: state of the art in the development of catalytic processes for the selective catalytic reduction of NOx into $\mathrm{N}_{2}$, Studies in Surface Science and Catalysis, 2007, 171: $1-23$.

[2] M.J. Albrecht, J.B. Rogan, System for controlling flue gas exit temperature for optimal SCR operations, U.S. Patent 6,609,483, 2003-8-26.

[3] R.N. Wiechard, J.M. Banas, R.D. Brown, Gas temperature control system for catalytic reduction of nitrogen oxide emissions, U.S. Patent 5,555,849, 1996-9-17.

[4] Jr.R.M. McNertney, S.P. Iannacchione, Passive system for optimal NOx reduction via selective catalytic reduction with variable boiler load, U.S. Patent 7,021,248, 2006-4-4.

[5] W. Nischt, J. Hines, K. Robinson, Update of selective catalytic reduction retrofit on a $675 \mathrm{MW}$ boiler at AES somerse, ASME International Joint Power Generation Conference, Miami, ASME, 2000: $1-8$.

[6] C. Dong, X.B. Wang, Application of economizer bypass on selective catalytic reduction system, Thermal Power Generation, 2014 (3): 96-100.

[7] D. Foerter, W. Jozewicz, Cost of selective catalytic reduction (SCR) application for nox control on coal-fired boilers, US Environmental Protection Agency, Office of Research and Development, 2001. 